\title{
A murine homolog of the yeast RNA1 gene is required for postimplantation development
}

\author{
James DeGregori, ${ }^{1,2,5}$ Andreas Russ, ${ }^{3}$ Harald von Melchner, ${ }^{3}$ Helen Rayburn, ${ }^{2}$ Prashant Priyaranjan, ${ }^{1}$ \\ Nancy A. Jenkins, ${ }^{4}$ Neal G. Copeland, ${ }^{4}$ and H. Earl Ruley ${ }^{1}$ \\ ${ }^{1}$ Department of Microbiology and Immunology, Vanderbilt University School of Medicine, Nashville, Tennessee \\ 37232-2363 USA; ${ }^{2}$ Center for Cancer Research and Department of Biology, Massachusetts Institute of Technology, \\ Cambridge, Massachusetts 02139 USA; ${ }^{3}$ Department of Hematology, University of Frankfurt Medical School, \\ Theodor-Stern-Kai 7, 6000 Frankfurt 70, Germany; ${ }^{4}$ Mammalian Genetics Laboratory, ABL-Basic Research Program, \\ National Cancer Institute-Frederick Cancer Research and Development Center, Frederick, Maryland 21702 USA
}

\begin{abstract}
A gene has been characterized that is required for postimplantation mouse development. The gene, designated fug1, was disrupted in embryonic stem cells by the U3Neo gene trap retrovirus, and the disrupted allele was introduced into the germ line. Homozygous mutant embryos arrest at the egg cylinder stage at about embryonic day 6 and are mostly resorbed by day 8.5. The appearance of the proamniotic cavity is delayed, and epiblast cells that surround the cavity are disorganized. fug1 transcripts are undetectable at E6 but are induced throughout the embryo after E6.5. The gene is expressed at low levels in all adult tissues examined, maps to chromosome 15, and is conserved among mammals. The cDNA sequence encodes a protein of 589 amino acids, the first 400 of which are $38 \%$ identical to the Saccaromyces cerevisiae RNA1 gene. Regions of greatest similarity include a long acidic domain and 11 leucine-rich motifs, thought to mediate high affinity protein-protein interactions. These similarities suggest that Fug1 may be required for developmental changes in RNA processing or chromatin structure prior to gastrulation.
\end{abstract}

[Key Words: fug1; yeast RNA1; mouse development; leucine rich motifs; insertional mutagenesis]

Received September 16, 1993; revised version accepted December 9, 1993.

Genes linked to recessive mutations that affect mammalian development have been difficult to isolate. Genetic screens are expensive and yield relatively few mutants. Recessive phenotypes can be identified only after backcrossing mutagenized animals, and developmental phenotypes, particularly those that result in early embryonic death, are usually apparent only after sacrificing animals during pregnancy. Consequently, most of the $\sim 1300$ genetic loci that have been described in mice (Green 1989) are associated with easily identified phenotypes affecting postnatal life. Even fewer genes that affect early embryonic development have been cloned (Gridley et al. 1990; Herrmann et al. 1990; Lee et al. 1992; Michaud et al. 1993; Zhou et al. 1993).

To circumvent some of the problems associated with conventional mouse genetics, gene trap vectors have been developed to disrupt genes expressed in embryonal stem (ES) cells (Gossler et al. 1989; Friedrich and Soriano 1991; von Melchner et al. 1992). The disrupted genes are introduced into the germ line and mice are bred to ho-

\footnotetext{
${ }^{5}$ Present address: Section of Genetics, Howard Hughes Medical Institute, Duke University Medical Center, Durham, North Carolina 27710 USA. ${ }^{6}$ Corresponding author.
}

mozygosity to assess gene functions. For example, we have developed retrovirus vectors that contain coding sequences for a selectable marker inserted into the U3 region of a defective Moloney murine leukemia virus (MLV) (von Melchner and Ruley 1989; Reddy et al. 1991; Chang et al. 1993). Provirus integration positions the U3 gene only 30 nucleotides from the flanking cellular DNA and selection for U3 gene expression generates clones in which the virus has integrated in or near $5^{\prime}$ exons of expressed cellular genes.

Several features of gene trap mutagenesis are particularly useful with regard to analyzing gene functions in mice. First, the mutation frequency following gene trap selection approaches $100 \%$. Thus, the transcribed sequences disrupted in cells recovered after gene trap selection have properties of genes transcribed by RNA polymerase II. They encode spliced transcripts, typically hybridize to single copy cellular DNA, and are expressed in cells prior to selection (Friedrich and Soriano 1991; Skarnes et al. 1992; von Melchner et al. 1992). Moreover, several integration sites have disrupted previously characterized genes (von Melchner et al. 1992; Pruitt 1992). This greatly reduces the number of animals needed to generate mutants, and the affected genes can be charac- 
terized even when the mutations cause no obvious phenotypes. Second, mutations in genes required for embryonic development are readily identified by the failure to recover offspring that are homozygous for the provirus insert. This has been observed with $>40 \%$ of the disrupted genes analyzed (Friedrich and Soriano 1991; Skarnes et al. 1992; von Melchner et al. 1992). Third, evidence from our laboratory suggests that most genes, including weakly expressed genes, can be targeted by gene trap mutagenesis (Chang et al. 1993). Finally, collections of ES cell clones can be screened in vitro for interesting mutations before being introduced into the germ line. For example, it is possible to screen for mutations involving developmentally regulated genes or genes with known sequence (Gossler et al. 1989; Reddy et al. 1992; von Melchner et al. 1992).

In this paper we have characterized a gene whose disruption by the U3Neo gene trap vector generates an embryonic lethal mutation. Mice homozygous for the disrupted allele arrest at the time in development at which the gene is normally induced (ca. embryonic day 6.5). The gene, designated fug1 (failure to undergo gastrulation) is similar to the RNA 1 genes of Saccharomyces cerevisiae and Schizosaccharomyces pombe.

\section{Results}

\section{Mice homozygous for the 1 B6 provirus die in utero}

The 1B6-neo ES cell clone was isolated by infecting D3 ES cells with the U3Neo gene trap retrovirus and selecting in G418, as described previously (von Melchner et al. 1992). Ribonuclease protection and Northern blot analysis indicated that the U3Neo gene was expressed from a promoter in the flanking cellular DNA. Sequences $5^{\prime}$ of the site of the proviral integration (isolated by inverse PCR) hybridized to single-copy cellular DNA and provided a probe that distinguished between the disrupted and normal alleles (not shown). While heterozygous mice carrying the 1B6 provirus appeared normal, none of the 34 offspring initially derived from crossing 1 B6 heterozygotes was homozygous for the integrated provirus (von Melchner et al. 1992). This suggested that the gene disrupted in 1B6 mice was required for embryonic development.

Heterozygous mice derived after four or more backcrosses into a $\mathrm{C} 57 \mathrm{Bl} / 6$ background were subsequently mated, but none of the 53 progeny was homozygous for the mutant allele (data not shown). Embryos were subsequently dissected at 13,11 , and 8.5 days postcoitum and genotyped by Southern blotting. Of the 55 conceptuses, 14 were resorbed, and no homozygous mutants were observed among the remaining 41 embryos (not shown). This suggests that mice homozygous for the $1 \mathrm{~B} 6$ provirus are lost in utero before day 8.5 but after implantation. In all, 84 heterozygotes and 44 wild-type homozygotes have been obtained from crosses between 1 B6 heterozygotes, similar to the ratio expected for a recessive lethal mutation. Further analysis suggested that homozygous embryos arrested in development prior to gastrulation (see below); consequently, the disrupted gene was designated fug1.

\section{Analysis of the gene disrupted by the 1 B6 provirus}

Sequences upstream of U3 gene trap proviruses cloned by inverse PCR frequently hybridize to transcripts expressed by the disrupted cellular genes. However, $5^{\prime}$ sequences flanking the 1B6 integration site failed to hybridize to cellular transcripts (von Melchner et al. 1992). We therefore isolated sequences downstream of the virus by anchored PCR (Frohman et al. 1988). The cloned PCR product (designated 1B6-13) contained genomic sequences $3^{\prime}$ to the provirus and were used to isolate cDNA clones of the fug1 gene. Comparisons between the fug1 cDNA and genomic sequences revealed that integration occurred in a 48-nucleotide exon (Fig. 1) only 16 nucleotides downstream from an intron/exon boundary. This accounts for the failure of the 5 '-flanking sequence to detect cellular transcripts by Northern blot hybridization. fug 1 transcripts are differentially spliced, as only one of three cDNAs spanning the integration site contained the 48-nucleotide exon. By Southern analysis, the 1 B6 provirus appears to have integrated normally, without causing obvious rearrangements, duplications, or deletions of host DNA (data not shown).

Twelve independent cDNAs derived from transcripts of the disrupted gene have been characterized. The 1B6-6 cDNA was isolated from a PCC3 embryonic carcinoma cell cDNA library (Stratagene) by using the 1B6-13 probe. The 1B6-6 cDNA was then used to isolate four other cDNAs from the same library. Finally, an almost fulllength cDNA (1B6-1) was used to probe an 8.5-day mouse embryonic cDNA library, resulting in 69 positive plaques (of $1.2 \times 10^{6}$ plaques), of which 7 were characterized. As estimated by their relative abundance in cDNA libraries, fug 1 transcripts comprise $\sim 0.006 \%$ of the total mRNA in 8.5 day embryos.

Although the fug1 cDNA sequence (Fig. 2) was similar in size to the transcript $(3 \mathrm{~kb})$ as measured on Northern blots (see below), primer extension analysis using D3 ES cellular RNA revealed that native transcripts extended an additional 101 nucleotides upstream of the $5^{\prime}$ end of

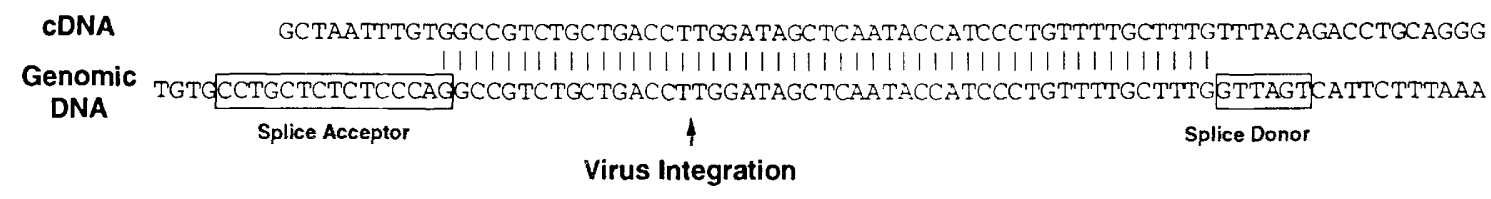

Figure 1. Integration site of the 1B6 provirus. Genomic sequences surrounding the 1B6 provirus were used to isolate cDNAs of the disrupted gene. Comparison of the cDNA and genomic sequences reveals a 48-nucleotide exon into which the provirus inserted. The site of provirus integration and splice acceptor and donor sites are indicated. 
the 1B6-16 cDNA clone (not shown). To isolate $5^{\prime}$ sequences, primers complementary to neo were used to amplify sequences appended to U3neo fusion transcripts by $5^{\prime}$ RACE (rapid amplification of cDNA ends) (Frohman et al. 1988). The 5' RACE products provided an additional 70 nucleotides of $5^{\prime}$ sequence, leaving $\sim 31$ nucleotides of the $5^{\prime}$ end of the transcript uncloned. The first ATG in the cDNA sequence is in a favorable context for translational initiation (Kozak 1991). A consensus polyadenylation signal and poly $(\mathrm{A})^{+}$tract are present at the $3^{\prime}$ end of the $1 \mathrm{~B} 6-14 \mathrm{~b}$ clone, and a $\mathrm{B} 1$ repeat is present in the $3^{\prime}$-untranslated region. The cDNA sequence has been confirmed in at least two independent clones except for 92 nucleotides at the $3^{\prime}$ end.

The 1 B6 target gene encodes a homolog of the yeast RNA1 protein

The $1 \mathrm{~B} 6$ cDNA sequence contains an open reading frame (ORF) of 589 amino acids and includes a highly acidic region composed of 27 glutamic acids and 11 aspartic

CAAAAATCCTCCTCCGCCGCCATAATCGGCTGGGGATCGTGGAGCAGGTGGTGTGCACGAGCTAAACGAGGAGCCGCGGCAGCAAGGAGA 90 GGCAAGCAGACTGGTCACTGGGCCTGGCCCCCACGCGGACTCTCAAGCAGTGACCGACGCGCGCGTTCCGTCCCCCCACGCCGCGGTGCC 180 GCTAATTTGTGGCCGTCTGCTGACCT^TGGATAGCTCAATACCATCCCTGTTTTGCTTTETTTACAGACCTGCAGGGGAGCCCGCCACTGC 270 AGCCATGGCCTCTGAAGACATTGCCAAACTGGCAGAGACCCTGGCTAAAACTCAGGTAGCCGGAGGGCAGCTGAGTTTTAAGGGCAAGGGT 361 $\begin{array}{lllllllllllllllllllllllllllllllllll}M & A & S & E & D & I & A & K & L & A & E & T & L & A & K & T & Q & V & A & G & G & Q & L & S & F & K & G & K & G\end{array}$ CTCAAACTAAATACTGCAGAAGATGCTAAAGATGTGATTAAGGAGATTGAAGAGTTTGACGGCCTCGAAGCTCTACGATTGGAGGGCAAC 451 $\begin{array}{llllllllllllllllllllllllllllllllllllll}L & K & L & N & T & A & E & D & A & K & D & V & I & K & E & I & E & E & F & D & G & L & E & A & L & R & L & E & G & N\end{array}$ ACGGTGGGCGTGGAAGCGGCCAGAGTCATCGCCAAGGCCTTAGAGAAGAAGTCTGAGCTGAAGCGATGCCACTGGAGTGACATGTTCACA 541 $\begin{array}{llllllllllllllllllllllllllllllllllll}T & V & G & V & E & A & A & R & V & I & A & K & A & L & E & K & K & S & E & L & K & R & C & H & W & S & D & M & F & T\end{array}$ GGAAGGCTTCGGTCTGAGATCCCACCAGCTCTGATCTCACTAGGGGAGGGACTCATCACTGCAGGAGCACAGCTGGTGGAACTGGACCTC 631

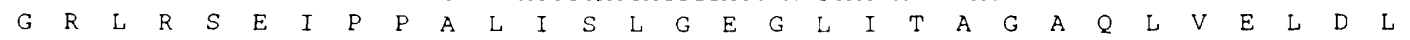
AGTGACAACGCATTTGGACCCGATGGAGTGCGAGGCTTCGAGGCCCTCCTCAAGAGCCCAGCCTGCTTCACCCTACAGGAACTCAAGCTT 721 $\begin{array}{llllllllllllllllllllllllllllllll}S & D & N & A & F & G & P & D & G & V & R & G & F & E & A & L & L & K & S & P & A & C & F & T & L & Q & E & L & K & L\end{array}$ AACAACTGTGGCATGGGCATCGGGGGTGGCAAGATTCTGGCAGCAGCTCTGACTGAGTGTCACCGCAAGTCCAGTGCCCAAGGCAAGCCC 811 $\begin{array}{lllllllllllllllllllllllllllllllllllll}N & N & C & G & M & G & I & G & G & G & K & I & L & A & A & A & L & T & E & C & H & R & K & S & S & A & Q & G & K & P\end{array}$ CTGCGCCTGAAGGTGTTTGTGGCTGGCAGAAATCGCCTGGAGAATGACGGAGCCACTGCACTGGCAGAAGCTTTTGGGATCATCGGGACT 901 $\begin{array}{llllllllllllllllllllllllllllllll}L & R & L & K & V & F & V & A & G & R & N & R & L & E & N & D & G & A & T & A & L & A & E & A & F & G & I & I & G & T\end{array}$ CTGGAAGAGGTGCATATGCCACAGAACGGAATTAACCATCCTGGTGTCACAGCCCTGGCCCAGGCCTTTGCCATCAACCCCCTGTTGCGA 991

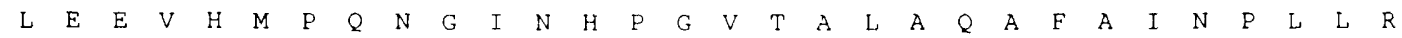
GTCATCAACCTAAATGACAACACCTTCACTGAGAAGGGTGGGGTGGCCATGGCTGAGACTCTGAAGACTCTGCGACAAGTGGAAGTGATC 1081 $\begin{array}{llllllllllllllllllllllllllllllllll}V & I & N & L & N & D & N & T & F & T & E & K & G & G & V & A & M & A & E & T & L & K & T & L & R & Q & V & E & V & I\end{array}$ AATTTTGGAGACTGCCTGGTGCGCTCTAAGGGTGCCGTTGCCATCGCAGATGCTGTCCGTGGTGGCCTGCCCAAGCTAAAGGAGCTGAAT 1171 $\begin{array}{lllllllllllllllllllllllllllllllllllll}N & F & G & D & C & L & V & R & S & K & G & A & V & A & I & A & D & A & V & R & G & G & L & P & K & L & K & E & L & N\end{array}$ CTGTCGTTCTGCGAAATCAAGAGAGATGCTGCCCTGGTTGTTGCTGAGGCTGTGGCCGACAAGGCTGAGCTGGAGAAGCTGGACCTCAAT 1261

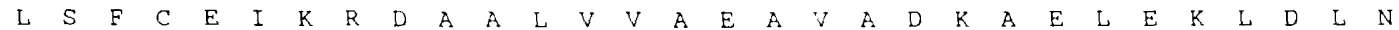
GGCAATGCCCTCGGAGAAGAGGGCTGTGAGCAGCTTCAGGAGGTGATGGACAGCTTCAATATGGCCAAGGTGCTGGCATCCCTCAGTGAT 1351 $\begin{array}{llllllllllllllllllllllllllllllllllllll}G & N & A & L & G & E & E & G & C & E & Q & L & Q & E & V & M & D & S & F & N & M & A & K & V & L & A & S & L & S & D\end{array}$ GATGAGGGAGAGGATGAAGATGAGGAGGAAGAAGGAGAAGAGGATGATGAGGAGGAGGAaGATGAAGAGGATGAGGAAGATGATGATGAG 1441 $\begin{array}{lllllllllllllllllllllllllllllllllll}D & E & G & E & D & E & D & E & E & E & E & G & E & E & D & D & E & E & E & E & D & E & E & D & E & E & D & D & D & E\end{array}$ GAGGAGGAGGAGCAGGAGGAAGAGGAAGAGCCTCCGCAGAGAGGGTCAGGGGAGGAGCCGGCTACACCCTCGAGGAAGATCCTGGACCCT 1531 $\begin{array}{llllllllllllllllllllllllllllllllllllll}E & E & E & E & Q & E & E & E & E & E & P & P & Q & R & G & S & G & E & E & P & A & T & P & S & R & K & I & L & D & P\end{array}$ AACAGTGGGGAGCCAGCTCCCGTGCTGTCCTCCCCGACTCCCACAGACCTCTCCACCTTCCTGTCATTCCCCTCCCCAGAGAAGCTGCTG 1621 $\begin{array}{llllllllllllllllllllllllllllllllllll}N & S & G & E & P & A & P & V & L & S & S & P & T & P & T & D & L & S & T & F & L & S & F & P & S & P & E & K & L & L\end{array}$ CGTCTGGGTCCCAAGGTCTCGGTGCTGATAGTCCAGCAGACTGATACCTCCGACCCAGAGAAGGTTGTTTCAGCCTTCCTGAAGGTGGCA 1711 $\begin{array}{llllllllllllllllllllllllllllllllllllllll}R & L & G & P & K & V & S & V & L & I & V & Q & Q & T & D & T & S & D & P & E & K & V & V & S & A & F & L & K & V & A\end{array}$ TCTGTGTTCAGGGATGACGCCTCAGTAAAGACCGCAGTGCTGGATGCCATCGATGCCCTCATGAAGAAGGCCTTCAGCTGCTCCTCTTTC 1801

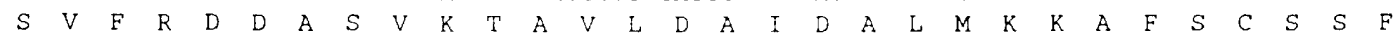
AATTCCAACACCTTCCTTACCAGGCTGCTCATCCACATGGGTCTGCTCAAGA GTGAAGACAAGATCAAGGCCATACCCAGCCTGCATGGC 1891 $\begin{array}{lllllllllllllllllllllllllllllllllll}N & S & N & T & F & L & T & R & L & L & I & H & M & G & L & L & K & S & E & D & K & I & K & A & I & P & S & L & H & G\end{array}$ CCCCTGATGGTGTTGAACCACGTGGTGAGGCAGGACTATTTCCCCAAGGCCCTTGCACCCCTGCTCTTGGCATTTGTGACAAAGCCCAAT 1981 $\begin{array}{llllllllllllllllllllllllllllllllllll}P & L & M & V & L & N & H & V & V & R & Q & D & Y & F & P & K & A & L & A & P & L & L & L & A & F & V & T & K & P & N\end{array}$ GGCGCGCTGGAAACCTGCTCCTTTGCCCGCCACAATCTGCTGCAGACGCTATACAACATCTAGATTTAAAGGCAGCTGCTTCTTGTCCC 2070 $\begin{array}{lllllllllllllllllllllllll}G & A & L & E & T & C & S & F & A & R & H & N & L & L & Q & T & L & Y & N & I\end{array}$

TCGCCCTGCCCCAGTGACTGAGGGTCTTGGATGGACTGAGCTCGGCCAGCATCTCCATTGGATATTTTGACCAGAGGAAGGGAGAGGGTC 2160 TTGTCTCCTGTGTCATATTGGTCCTTTGATACTGTGTTGGTTTGGTGTGTGTGTGTGGGTATGTACTTCCTGTCTGGATTGCAGATCTTC 2250 ATCTCCCTGCTGGACTAACCCAAGTCCACTGTGGGGAATTGATGCCTAGGGGAAGGGTAGAAAGCTGCTTTGTTATTAAACTTAGGCCAA 2340 CTTAGCCATAGGCCCCCGTTGGCTGTCCTGTCTGCCCTGCCTTCCTGTCCCACCAAAGCCTGGGAATTCTGATCCGTGCTGTGTCCACCG 2430 TGGAGTCCTAAATAACAGAGGCTATCAGACGATGGGCTATCATTAGAAAGGTAAAAACTCAGGTGGTACATGCCTTAATCCCAGACTCAG 2520 GAACAGAGGCAAGAATTCTGAGTTTGAGGCCAGCCTGGTCTACAAAGTGAGTTCCAGGACAGCCAGGTCTATACAGAGGAACCCTGTCTC 2610 AAAAAAACAAAAACAAAAAAAAAAAAACCTCTGCCCTTAACCATGTGACTTGGAGGAGCAGCCAGGGGAGTGGGAGCTGTCTGGGGTAAC 2700 CTGGCTCTAGGACCAGGTGGAAAAAGCACCTTGCTGCCCAGCCCTGTTCTTCTCCTGGGGAGGGGAAGGGCAGGTCCCCTAATGCCTGAA 2790 CCACATGTTGGGCCTACTCTCTGAGGGTTTTCTAAGACAGGAGTGTGTAATAGGGATGGAGCCGGGTAAGAGATGCTCTGTGACTTCCCG 2880 AATGGGCTGCTTGGCCACCTCCTACTTCCCGTTGTGTTGTGTGTCTGCTGTGCCCGGGAGCTTCACAAATAAACGTCATCTGTGTAGTTG 2970 CAAAAAAAAAA

Figure 2. Sequence of fug1 cDNA. The nucleotide sequence and deduced amino acid sequence for the longest open reading frame (ORF) are shown. The integration site for the 1B6 provirus is shown ( $)$. An alternatively spliced 48-nucleotide exon and polyadenylation signal are underlined. A B1 repeat encompasses nucleotides. 2490-2637. 
acids, interrupted by only 2 glycines and 1 glutamine (Fig. 2). Analysis of the predicted translation product by the MacVector (IBI) and Prosite (Intelligenetics) programs did not reveal known protein sequence domains indicative of possible function. However, the FastDB (Intelligenetics/ program revealed a striking similarity between the 1B6 ORF and the RNAl protein of $S$. cerevisiae. The aligned protein sequences show $38 \%$ amino acid identity and $47 \%$ similarity over the entire length (407 amino acids) of RNA1. Subsequently, the sequence of the S. pombe RNA1 gene was reported (Melchior et al. 1993). As shown in Figure 3, Fugl is nearly as similar to the two yeast proteins as they are to each another.

RNAl is a member of a larger group of proteins that possess leucine-rich motifs (LRMs) (Schneider and Schweiger 1992; Melchior et al. 1993). LRMs are thought to mediate protein-protein interactions, such as the tight binding of the ribonuclease/angiogenin inhibitor to angiogenin. The 11 LRM repeats and a long acidic domain comprise the regions of greatest similarity (Fig. 3). Two amino acids mutated in the temperature-sensitive lethal rna1-1 allele and required for the mutant phenotype (Traglia et al. 1989) are also present in Fugl. However, the carboxy-terminal regions are not conserved, as Fugl is 182 amino acids longer than RNAl of S. cerevisiae. Whereas the significance of the extra sequence is unknown, the carboxy-terminal region of RNAl beyond the acidic domain can be deleted without affecting function (Traglia et al. 1989).

\section{The Fugl gene is activated prior to gastrulation} and is widely expressed in adult tissues

The expression of fug1 was assessed by Northern blot analysis of total cellular RNAs using the 1B6-1 cDNA as a probe. All adult tissues examined (Fig. 4), as well as several established fibroblast cell lines (data not shown), expressed similar levels of a $3-\mathrm{kb}$ transcript. The autoradiograms of the same Northern blot, probed with either 1B6-1 or glyceraldehyde 3-phosphate dehydrogenase |GAP|, indicated that the ratio of fug1 to GAP transcripts in the uninfected D3 cells was more than twofold greater than in 1B6 cells (Fig. 4). This would be expected if proviral integration greatly reduced the expression from the affected allele.

Whole-mount in situ hybridization was performed on normal mouse embryos between 6 and 9.5 days of embryonic development (Fig. 5; data not shown). Embryos were dissected out of the yolk sac, and the ectoplacental cone was removed. The embryos were also sectioned to provide a more detailed analysis of expression (Fig. 6). fug1 was ubiquitously expressed in 8.5- and 9.5-day embryos as observed both in whole embryos and in sections (data not shown). In sections of 7.5-day embryos (Fig. 6), modest expression was seen throughout the embryo, in both embryonic and extraembryonic tissues. However, expression was highest in the embryonic ectoderm (Fig. $6 \mathrm{Cl}$ and lowest in the most posterior part of the primitive streak. This is the part of the streak that contributes to the extraembryonic mesoderm (Lawson and Pederson 1992). In short, highest levels were observed in the cells that form the embryo proper. Ectoderm was also preferentially stained with probes for the constitutive GAP gene (Fig. 6E), which may reflect the higher cell density. However, unlike fug1, GAP expression was always uniform within the ectoderm. fug1 expression was reproducibly low (in three experiments) in 6.5-day embryos (Fig. 5; data not shown), even after 24 hr of alkaline phosphatase reaction. Some 6.5-day embryos exhibited faint staining above background while others were indistinguishable from controls. Importantly, 6-day embryos show no staining (Fig. 5). These results suggest that fug1 expression is regulated during embryogenesis, with levels increasing dramatically just prior to gastrulation.

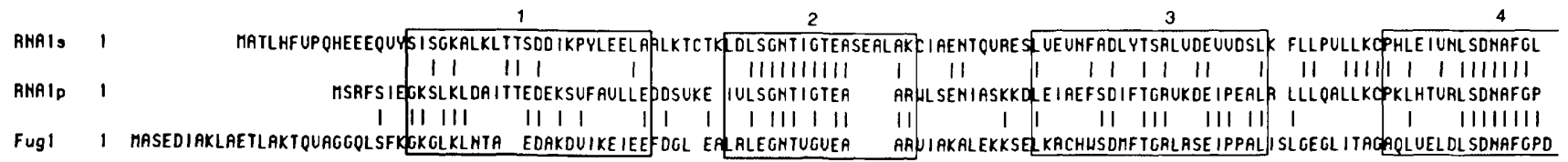

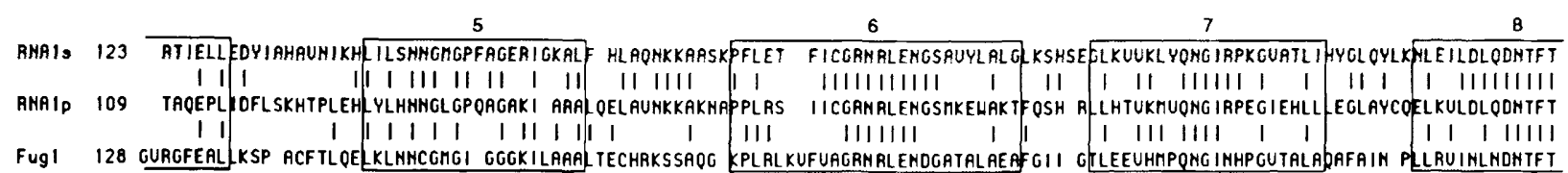

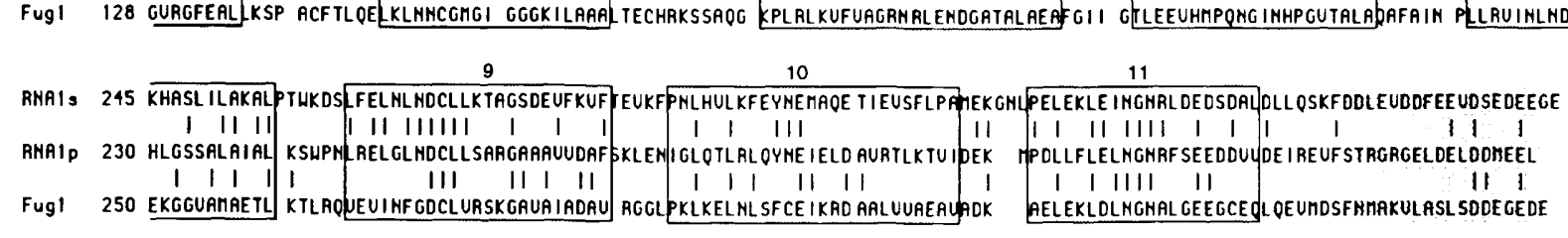

ANA1s 367 DEEDEOEDEKLEEIETERLEKELLEUQUDDLAERLAETE IK 407 111111
RNA IP 348 DEEEEOE EEEAESOSPEPETSEEEKEOKELADELSKAHI

Fug1 366 DEEEEGE EDDEEEEDEEDEEDODEEEEEQEEEEEPPQRGS...589

Figure 3. Alignment of mouse and yeast RNAl protein sequences. The sequences of the RNAl proteins from $S$. cerevisiae (RNAls), and $S$, pombe (RNAlp) are aligned with amino acids $1-405$ of the Fug1 protein (Fug1). Vertical lines indicate amino acid identity. Boxes indicate the LRMs in RNAl as noted elsewhere (Schneider and Schweiger 1992). The acidic domains of the proteins are shaded.
} 

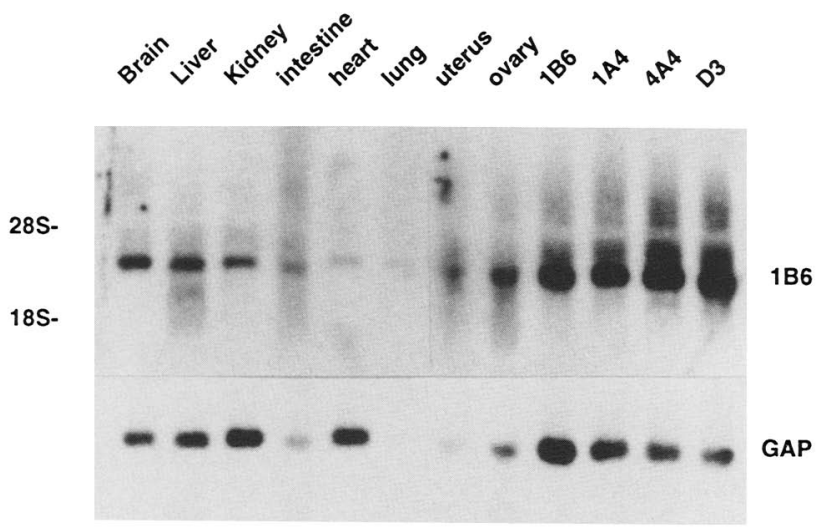

Figure 4. Northern analysis of fug1 transcripts from different tissues. Unselected $(20 \mu \mathrm{g})$ RNA from the indicated mouse tissue or ES cell line was first hybridized to a ${ }^{32} \mathrm{P}$-labeled 1B6-1 cDNA probe and then stripped and hybridized to a GAP probe, as indicated. The migration of the $28 \mathrm{~S}$ and $18 \mathrm{~S}$ RNAs are indicated. The 1B6-1 and GAP blots were exposed for 4 days and 8 hr with enhancing screens, respectively.

\section{Effects of virus integration on fugl gene expression}

The 48-nucleotide exon into which the $1 \mathrm{~B} 6$ provirus integrated is alternatively spliced, as it was present in only one of three cDNAs. To measure the relative abundance of each transcript, primers on either side of the exon were used to amplify reverse transcription products obtained with RNA from different tissues and cell lines. In all tissues examined, transcripts containing (fug1 B) and lacking (fug1 A) the 48-nucleotide exon were present at a ratio of $\sim 1: 3$ (data not shown). The fug1 B transcript was not detected in two rat cell lines (RAT1 and REF52), while it was present in two mouse cell lines $(10 \mathrm{Tl} / 2$ and D3) (data not shown). Together, these results suggest that alternative splicing has little significance with regard to gene regulation.

It was important to understand the extent to which the 1B6 provirus interfered with fug1 expression. While fug1-U3Neo fusion transcripts terminate almost exclusively in the $5^{\prime}$ long terminal repeat (LTR) /von Melchner et al. 1992), it was possible that some fug1 A transcripts could be expressed by splicing around the provirus. We tested whether fug1 sequences downstream of the provirus were expressed in presumptive 1B6 homozygotes by in situ hybridization. If expression of sequences $3^{\prime}$ of the integration site was abolished, then homozygous embryos should not hybridize to the 1B6-1 cDNA probe. As summarized in Table 1 and illustrated in Figure 5, approximately one-fourth of the 7.5- and 8.5-day embryos derived from inbreeding 1B6 mice were negative for fug1 expression. These embryos were smaller and less developed than normal and thus appeared to be homozygous mutants. These results suggest that the $1 \mathrm{~B} 6$ provirus induced a null mutation. However, as fug1 transcripts are undetectable before E6.5 (Fig. 5), the lack of fug1 expression could result from failure of homozygous embryos to develop beyond the point at which the gene is expressed.

\section{Phenotype of embryos homozygous for the $1 B 6$} provirus

Embryos presumably homozygous for the $1 \mathrm{~B} 6$ provirus were identified based on the occurrence of abnormal embryos ( one-fourth of all embryos) in crosses between $1 \mathrm{~B} 6$ heterozygotes but not in crosses in which one or both of the parents were wild type (Table 1). The failure of these abnormal embryos to express fug1 suggested further that they represent 1B6 homozygotes. At E7.5 these embryos were one-fourth to one-third normal size (Figs. 5 and 7) and lacked a discernible exocoelom and ectoplacental cavity. Additionally, the ectoplacental cone did not appear to be vascularized as it is in normal embryos (data not shown). The absence of vascularization could be due to a halt in development of the embryo prior to the initiation of the uterine reaction. Alternatively, it could be a consequence of the rejection of the embryo by the uterus. Abnormal embryos were also seen at E6.5. These embryos were half the size of their normal siblings and were similar in appearance to E7.5 mutants, albeit $25-50 \%$ smaller (Fig. 7). Only two abnormal embryos were observed at E8.5. One was recovered (Table 1) and appeared similar in size to the E7.5 mutants (data not shown). In summary, homozygous mutants arrest in development around E6, continue to grow until E7-E8.5, and most are resorbed by E8.5 (Table 1).

Sections of mutant embryos at E6.5, E7.5, and E8.5 revealed two embryonic cell layers, presumably representing the primitive endoderm and ectoderm or epiblast (Fig. 7; data not shown). The mutant embryos contained what appeared to be a small proamniotic cavity that was sometimes observable at E7.5 (Fig. 7) and was relatively large in one mutant at E8.5 (data not shown). However, while the primitive ectoderm forms an organized columnar epithelium surrounding the cavity in normal embryos, there was little or no organization of the ectoderm in mutant embryos (Fig. 7). The embryonic cells also appeared less cohesive, as compared with the tight epithelium of normal embryos. The mutants lacked an obvious mesoderm layer, even at E8.5. However, mesoderm cells could be present, but disorganized. In summary, fug1 appears to be required for the organization of the primitive ectoderm around the proamniotic cavity.

\section{fugl is conserved among mammals}

The phylogenetic conservation of fug1 was assessed by probing DNAs from different species ("zoo blot") with the 1B6-1 cDNA. As shown in Figure 8, hybridization was only observed in mammals, suggesting that fug1 sequences are not highly conserved. Reducing the stringency of hybridization did not reveal any cross-reactive bands in zebrafish, Drosophila, or any additional bands in yeast DNA (data not shown). Finally, fug1 appears to be present as a single-copy gene in mice, as only a single hybridizing band was detected by the 1B6-1 probe following digestion with either Sall or Smal (data not shown). 
Figure 5. fug1 is expressed in 7.5-day embryos but not in 6-day or mutant embryos. (A) 7.25-Day embryos derived from inbreeding 1B6 heterozygotes. (M) Presumptive mutant embryos; (W) normal embryos. All were hybridized in situ with an antisense $1 \mathrm{~B} 6-1$ probe. Color reactions proceeded overnight. $(B)$ 7.5-Day embryos hybridized either with the 1B6-1 sense (S) or antisense (AS) probes and reactions were developed for $4 \mathrm{hr}$. 6.5-Day $(C, E)$ or 6-day embryos $(D)$ hybridized with a 1B6-1 antisense $(C, D)$ or sense $(E)$ probe. For $C-E$, color reaction proceeded overnight. The embryos in $C, D$, and $E$ were enlarged threefold relative to the embryos in $A$ and $B$.

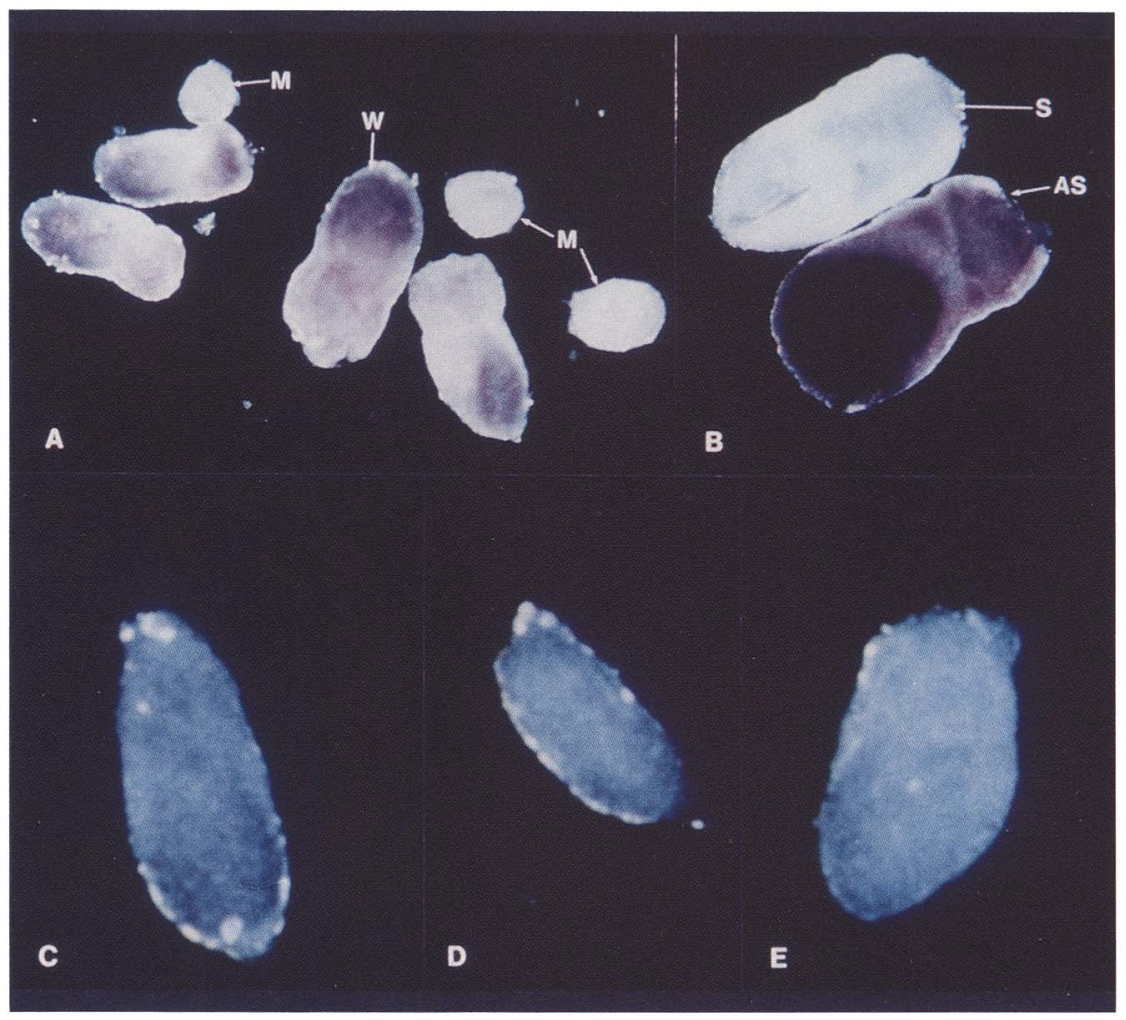

\section{Fugl maps to chromosome 15}

The mouse chromosomal location of Fug1 was determined by interspecific backcross analysis using progeny derived from matings of $\{[\mathrm{C} 57 \mathrm{BL} / 6] \times$ Mus spretus $\}$ Fl $\times$ C57BL/6J] mice. This interspecific backcross mapping panel has been typed for $>1300$ loci that are well distributed among all the autosomes as well as the $\mathrm{X}$ chromosome (Copeland and Jenkins 1991). C57BL/6) and $M$. spretus DNAs were digested with several enzymes and analyzed by Southern blot hybridization for informative restriction fragment length polymorphisms (RFLPs) using a mouse cDNA fug1 probe. A 6.8-kb $M$. spretus HincII RFLP (see Materials and methods) was used to follow the segregation of the fug 1 locus in backcross mice. The mapping results indicated that Fug1 is located in the distal region of mouse chromosome 15 linked to thyroglobulin (Tgn), simian sarcoma oncogene (Sis) and glycerol phosphate dehydrogenase $1(G d c l)$. Although 144 mice were analyzed for every marker, up to 171 mice were typed for some pairs of markers. Each locus was analyzed in pairwise combinations for recombination fequencies using the additional data. The ratios of the total number of mice exhibiting recombinant chromosomes to the total number of mice analyzed for each pair of loci and the most likely gene order are centromere- Tgn-12/147-Fug1-0/157-Sis-23/171-Gdcl. The recombination frequencies [expressed as genetic distances in centiMorgans $(\mathrm{cM}) \pm$ the standard error are$\operatorname{TgM}-8.2+/-2.3[$ Fug 1, Sis] $13.5+/-2.6-G d c 1$. No recombinants were detected between Fug1 and Sis in 157 animals typed in common suggesting that the two loci are within $1.9 \mathrm{cM}$ of each other (upper $95 \%$ confidence limit).

We have compared our interspecific map of chromosome 15 with a composite mouse linkage map that reports the map location of many uncloned mouse mutations (compiled by M.T. Davisson, T.H. Roderick, A.L. Hillyard, and D.P. Doolittle and provided from GBASE, a computerized data base maintained at The Jackson Laboratory, Bar Harbor, ME). fug1 mapped in a region of the composite map that contains one mouse mutation, blind (Bld) (Watson 1968). Heterozygotes for Bld are blind, and homozygotes die by day 8 of embryonic development (Vankin and Caspari 1979). Presumptive Bld homozygotes lose contact with uterine tissue and are retarded in growth as early as E6. By E7.5, the mutants formed amniotic folds and limited mesoderm, which we have not observed in fug1 homozygotes. Due to a similar map position and similar timing of embryonic death, Bld may be an allele of fug1. Unfortunately, we have been unable to test this possibility because Bld mice are no longer available (M. Watson, pers. comm.).

\section{Discussion}

Gene trap mutagenesis provides an effective means to study gene functions in mice. In the present study, we have characterized a gene that was disrupted in ES cells by the U3Neo gene trap retrovirus and subsequently introduced into the germ line. The disrupted gene, designated fug1, appears to be a mammalian homolog of the yeast RNA1 gene. Homozygous mutants arrest at the egg 


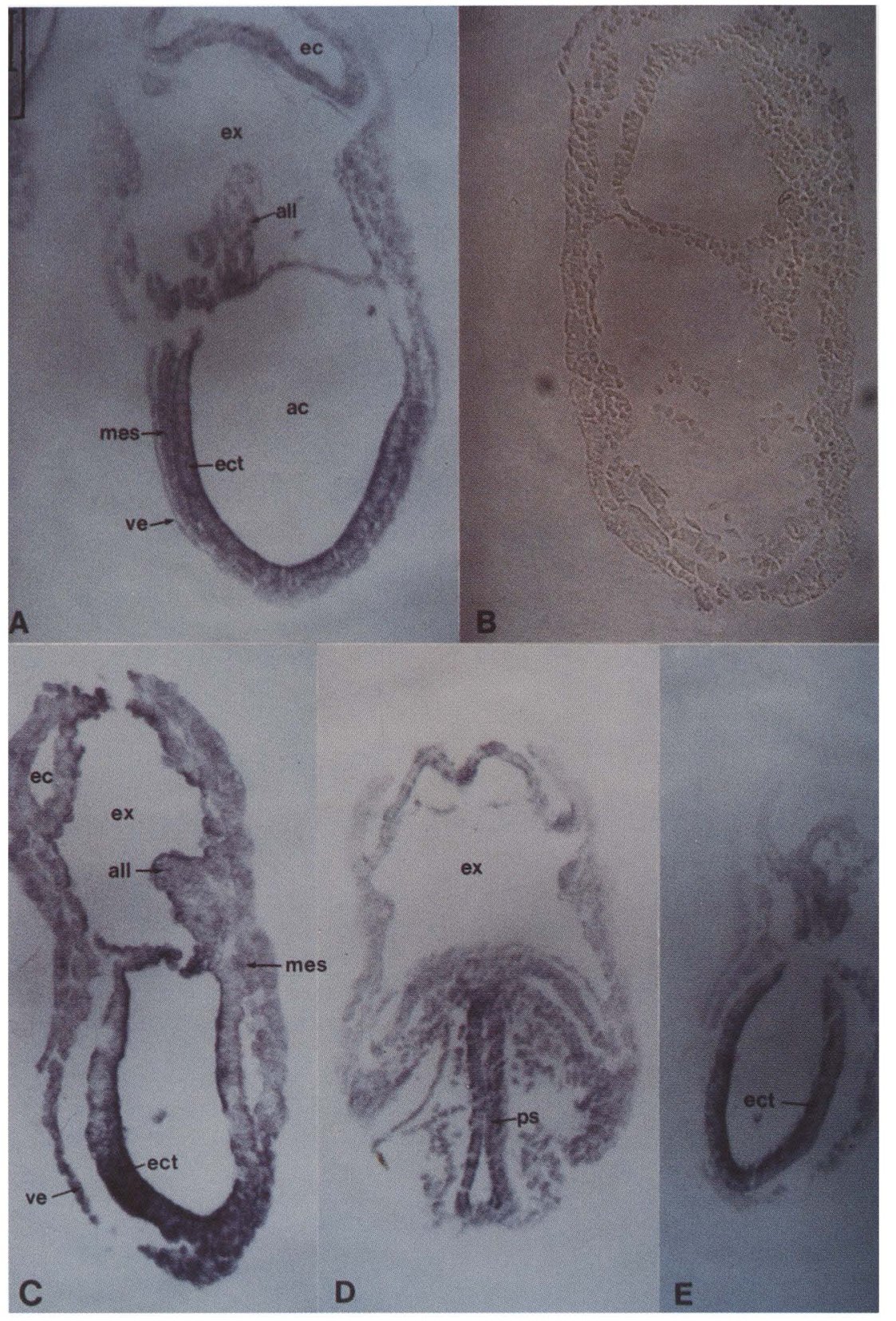

Figure 6. fug1 expression in gastrulation stage embryos. Embryos (around E7.5) were hybridized in situ with either with a 1B6-1 anti-sense $(A, C, D)$ or sense $(B)$ probe or an antisense GAP probe $(E)$ and then sectioned. Color reactions went for $4 \mathrm{hr}(E), 6$ hr. $(A, C, D)$, and overnight $(B)$. (ec) Ectoplacental cavity; (ex) exocoelom; (ac) amniotic cavity; (al) allantois; (ect) ectoderm; (mes) mesoderm; (ve) visceral endoderm. cylinder stage of embryonic development, just prior to the time at which the gene is normally induced. Following gastrulation, fug1 is expressed in all embryonic and adult tissues examined.

\section{Activation of U3Neo gene expression}

Earlier Northern blot and ribonuclease protection experiments indicated that gene trap selection generates proviruses that have inserted in or near $5^{\prime}$ exons of expressed cellular genes (von Melchner et al. 1992). U3 fusion transcripts were expressed from flanking cellular promoters and contained an average of 2-300 nucle- otides of cellular RNA. In the present study, we show that this mechanism was responsible for the activation of U3 gene expression in the 1B6 clone. U3Neo transcripts were expressed as a result of integration into a $5^{\prime}$ exon of the fug1 gene and contained $\sim 225$ nucleotides of appended cellular RNA. As has been observed previously (von Melchner and Ruley 1989; von Melchner et al. 1992), the target gene was expressed in ES cells prior to virus integration and was not activated as a result of integration. Integration occurred only 16 nucleotides from an intron/exon junction, accounting for the failure of 5'-flanking sequences to hybridize to cellular transcripts (von Melchner et al. 1992). Finally, fug1 tran- 
Table 1. Developmental arrest and lack of target gene expression in embryos homozygous for the 1 B6 integration

\begin{tabular}{lcccc}
\hline Cross & Age & Normal & Abnormal & Resorbed \\
\hline Het $\times$ Het & E8 & 34 & $2(0 / 1)$ & 15 \\
Het $\times$ Het & E7 & $90(21 / 21)$ & $17(0 / 5)$ & 11 \\
Het $\times$ Het & E6 & 32 & 13 & 0 \\
Het $\times$ WT & E8 & 7 & 0 & 0 \\
Het $\times$ WT & E7 & 19 & 0 & 0 \\
Het $\times$ WT & E6 & 9 & 0 & 0 \\
WT $\times$ WT & E8 & 62 & 0 & 3 \\
WT $\times$ WT & E7 & $110(36 / 36)$ & 0 & 5 \\
WT $\times$ WT & E6 & 32 & 0 & 2 \\
\hline
\end{tabular}

Summarized are the phenotypes of embryos recovered from crossing mice heterozygous for the $1 \mathrm{~B} 6$ provirus after 6,7 , or 8 days p.c. Embryos designated E8, E7, and E6 represent embryos staged between $6-6.9,7-7.9$, and $8-8.5$ days of embryonic development (Theiler 1989). Embryos were isolated by dissection and classified as normal or abnormal. Abnormal embryos were approximately one-third normal size. Numbers in parentheses indicate the number of stained and unstained embryos as determined by in situ hybridization, probing with cDNA sequences $3^{\prime}$ of the site of provirus integration (1B6-1).

scripts are not highly expressed $(<0.01 \%$ total mRNA), as estimated either by Northern blot hybridization or by their representation in cDNA libraries. Thus, even weak promoters are capable of activating U3 gene expression, as suggested previously (Chang et al. 1993).

\section{Recessive lethal phenotype resulting from loss of fugl expression}

Several observations suggest that insertional disruption of the fug1 gene is responsible for the recessive lethal phenotype observed in 1B6 homozygotes. First, the 1B6 provirus was backcrossed into $\mathrm{C} 57 \mathrm{Bl} / 6$ mice for five generations and was invariably linked to embryonic death among the 128 inbred progeny genotyped. Consequently, any second site mutation causing this phenotype would have to be closely linked to the provirus. Second, the provirus appears to abolish fug1 gene expression, as fusion transcripts terminate in the $5^{\prime}$ LTR, and we were unable to detect fug1 transcripts $3^{\prime}$ of the provirus in homozygous mutant embryos. Third, developmental arrest occurs around the time at which the fug1 gene is normally induced, around E6.5. Finally, embryonic death was probably not caused by expression of the neo transgene, as high levels of neomycin phosphotransferase have been constitutively expressed throughout development without detrimental effects (Friedrich and Soriano 1991; M. Roshon and H.E. Ruley, unpubl.).

\section{fugl is required for postimplantation development}

Little is known about the genes required for the differentiation of the primitive ectoderm and endoderm, the formation of the proamniotic cavity, and the organization of the ectoderm into an organized epithelium. Al- though a number of mutations have been described that result in embryonic death at or before gastrulation (Green 1989), only a few of the responsible genes have been cloned (Herrmann et al. 1990; Lee et al. 1992; Zhou et al. 19931.

fug1 is required for the organized development of the egg cylinder stage embryo and subsequent gastrulation. Embryos homozygous for the disrupted fug1 allele form a proamniotic cavity, but only after a considerable delay. Ectodermal cells surrounding the cavity are disorganized, even in mutants found at E8.5. The ectodermal cells may be impaired in their ability to organize into an epithelium; alternatively, cell-cell contacts may form but are not maintained.

Several observations suggest that fug1 is not simply required for cell viability. Defects are not observed until E6, after maternal RNAs are typically degraded (Sawicki et al. 1981) and after embryos require at least some de novo gene expression (Johnson 1981). Moreover, the mutant embryos continue to grow for several days after abnormalities are first observed, and the cells remain intact as judged by microscopic examination of tissue sections. Nevertheless, we cannot exclude the possibility that maternal or early embryonic products can maintain viability until E8.5.

\section{Fug1 is similar to the yeast RNA1 protein}

Fugl is related to the RNAl proteins of $S$. cerevisiae and $S$. pombe. The regions of greatest similarity include a large acidic domain and 11 LRMs, thought to mediate high affinity protein-protein interactions (Schneider and Schweiger 1992). RNA1 is essential for yeast cell viability. Both loss-of-function and temperature-conditional mutations cause pleotropic defects in the synthesis, processing, and nuclear transport of precursors for all three classes of RNA (Hopper et al. 1978; Atkinson et al. 1985; Forrester et al. 1992). Remarkably, RNAl protein appears to be localized to the cytoplasm (Hopper et al. 1990), and like RNAl, Fugl possesses no obvious nuclear localization signal.

Some of the effects of RNA1 on RNA metabolism are nearly identical to those caused by $P R P 20$ (Forrester et al. 1992), suggesting that the two genes may function in the same pathway. Consistent with this notion, SRN1, a negative regulator of carbon catabolite repression, suppresses both RNA1 and some PRP mutations (Pearson et al. 1982; Tung et al. 1992). Because PRP20 encodes a nuclear protein (Fleischmann et al. 1991), it may be a target of a cytoplasmic activity controlled by RNA1.

RNA1 appears to affect RNA metabolism indirectly, as it is excluded from the nucleus and (like fug1) is expressed at low levels (Traglia et al. 1989). Moreover, splicing defects seen in vivo are not observed with mutant cell extracts in vitro (Atkinson et al. 1985). How does RNAl exert such pleotropic effects on RNA metabolism? One possibility is that RNAl may influence chromatin structure, as has been suggested of PRP20 (Forrester et al. 1992).

At this point we do not know whether biochemical 


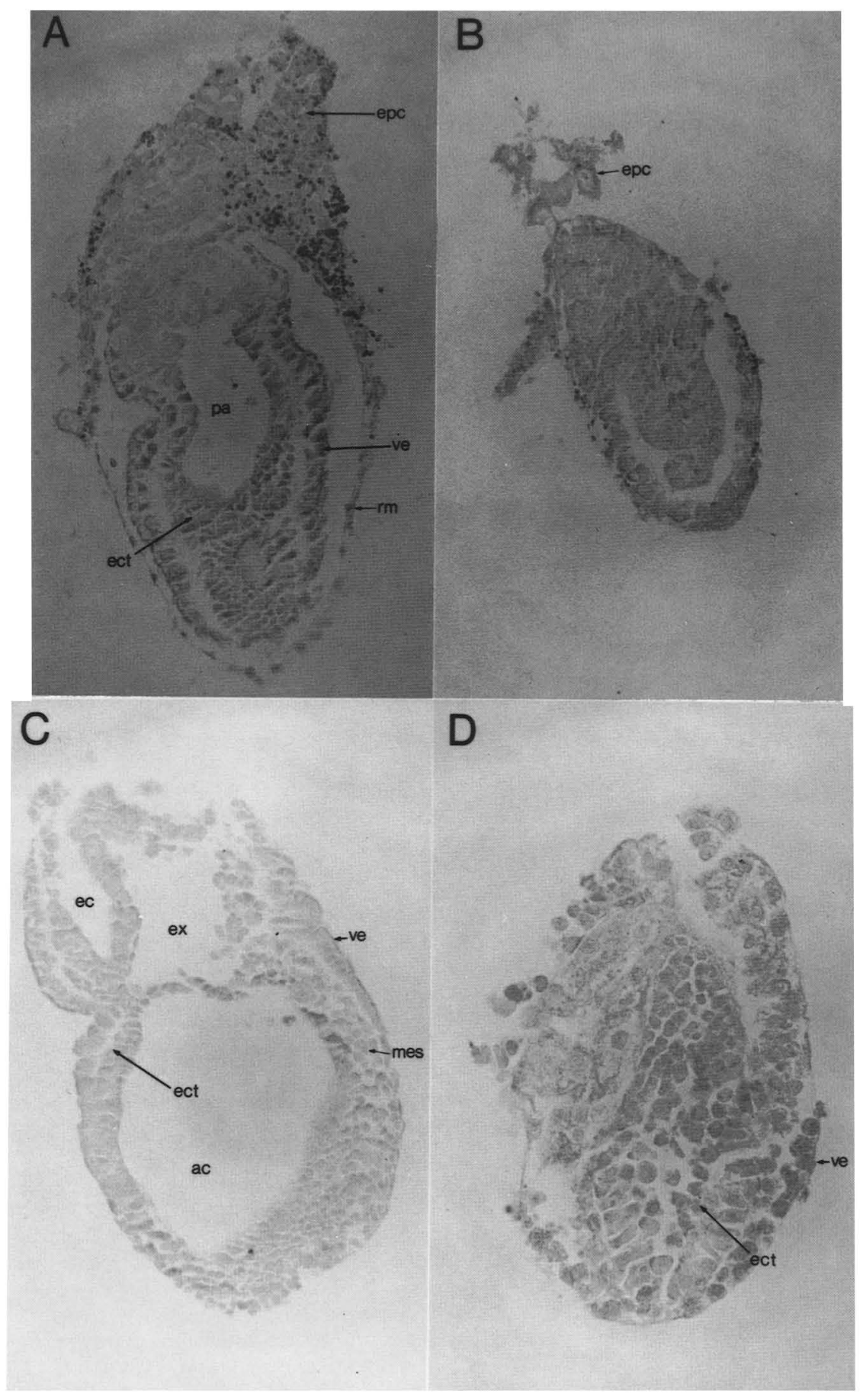

Figure 7. Sections of normal and abnormal 6.5- and 7.5-day embryos. Embryos were derived from inbreeding $1 \mathrm{~B} 6$ heterozygotes and serially sectioned. Representative sections of normal 6.5- and 7.5day embryos are shown in $A$ and $C$, respectively, and representative sections of mutant 6.5- and 7.5-day siblings are shown in $B$ and $D$, respectively. Photomicrograph of mutant embryo in $D$ is enlarged three times that of the normal littermate $(C)$. (epc) Ectoplacental cone; (pa) proamniotic cavity; (ect) primitive ectoderm; (ve) visceral endoderm; $(\mathrm{rm})$ Reichert's membrane; (ec) ectoplacental cavity; (ex) exocoelom; (ac) amniotic cavity; (mes) mesoderm; (ect) ectoderm; (ve) visceral endoderm. functions of RNA1 are conserved by Fug1, as similar proteins (e.g., Ras) may function quite differently in mammalian cells and yeast (Lowy and Willumsen 1993). The additional 182-amino-acid residues at the carboxyl terminus of Fugl may also indicate functional differences. Future studies will therefore address a number of questions, including the following: (1) What are the biochemical functions of RNAl and Fugl, and are these conserved? (2) Can protein partners thought to interact with LRMs of Fugl and RNAl be identified and are they related? (3) How does the activation of fug1 expression between E6.5 and E7 influence development? Specifically, is fug1 required for widespread changes in chromatin structure and gene expression (Cedar and Razin 1990; Kafri et al. 1992) that occur during this period? The identification of a mammalian RNAl homolog and its insertional disruption in mice will assist efforts to answer these questions. 


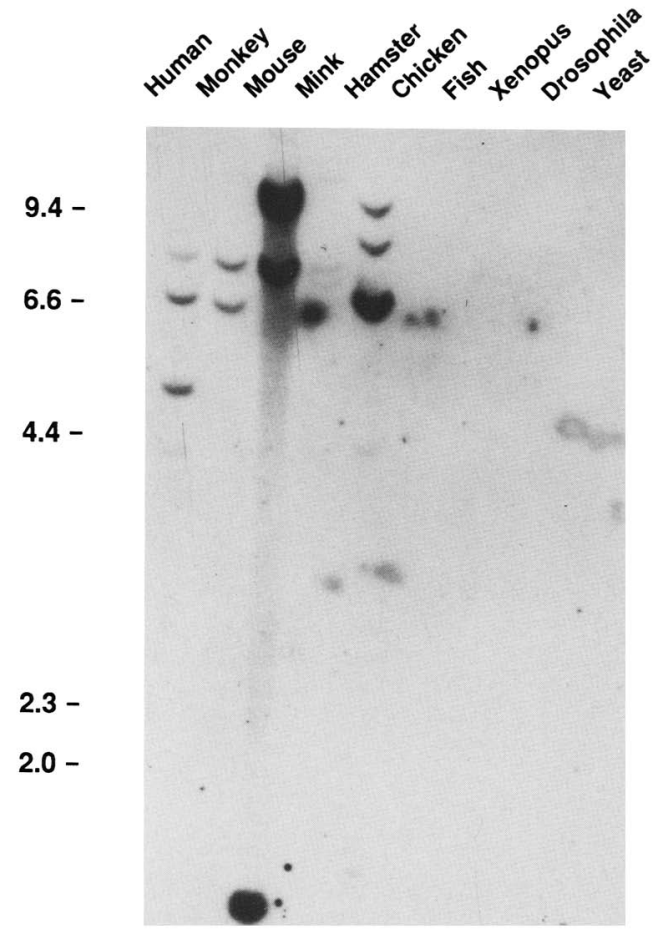

Figure 8. fug1 is conserved in mammals. Southern analysis of DNA from different organisms: $10 \mu \mathrm{g}$, unless otherwise indicated, of either the indicated organism or cell line was digested with EcoRI and hybridized to ${ }^{32} \mathrm{P}$-labeled probes derived from the entire 1B6-1 cDNA sequence. Drosophila DNA is from Drosophila melanogastor, Fish is from zebrafish, and yeast is from $S$. cerevisiae. The CV-1 cell line was used for monkey DNA, CCL64 for mink, CHTG49 for hamster, and D3 for mouse. Mink DNA $(2 \mu \mathrm{g})$ was underloaded relative to other mammalian DNAs. The blot was hybridized at $42^{\circ} \mathrm{C}$ overnight as described in Materials and methods and washed two times each in $2 \times, 1 \times$, and $0.2 \times \mathrm{SSC}$ for $20 \mathrm{~min}$ each at $68^{\circ} \mathrm{C}$. Size markers, in $\mathrm{kb}$, are indicated.

\section{Materials and methods}

Nucleic acid blot hybridization

DNA and RNA were isolated from cultured cells or tail biopsies as described previously (Laird et al. 1991; Titus 1991). Southern and Northern blots (Sambrook et al. 1989) were transfered to Hybond $\mathrm{N}+$ nylon membranes (Amersham) and hybridized to $\left[{ }^{32} \mathrm{P}\right] \mathrm{dCTP}-\mathrm{labeled}$ probes (Feinberg and Volgelstein 1984).

\section{Primer extension, $R T-P C R$, and $5^{\prime} R A C E$}

Primer extension analysis of fug 1 transcripts was performed as described (Sambrook et al. 1989), using $10^{6} \mathrm{cpm}$ of $5^{\prime}$ end-labeled primer, annealing overnight at $30.5^{\circ} \mathrm{C}$.

RT-PCR was performed as described (Innis et al. 1990), using primers EX-1: 5'-ACGCGGACTCTCAAGCAGTGA-3' and EX-2: $5^{\prime}$-TTGCCCTCCAATCGTAGAGCTT-3') as flanking primers.

5' RACE (Frohman et al. 1988) was performed using three nested primers complementary to the U3Neo-coding strand and an anchor/adapter primer combination. Specific primers were as follows: NeoA, $5^{\prime}$-attgtctgttgtgcccagtcata; NeoB, $5^{\prime}$-CGAAT-
AGCCTCTCCACCCAA; NeoC, 5'-CCATCTTGTTCAATCATGCGAAACGATCC; anchor, 5'-ATTGAATTCTCTAGAACGCGTCTCGAG $(T)_{20} ;$ and adaptor, 5'-ATTGAATTCTCTAGAACGCGTCTCGAG. Total cellular RNA $(10 \mu \mathrm{g})$ was reverse transcribed for $90 \mathrm{~min}$ at $45^{\circ} \mathrm{C}$ in $25 \mu \mathrm{l}$ of reaction mix containing $1 \times$ PCR buffer (Perkin Elmer), $200 \mu \mathrm{M}$ DNTPs (PerkinElmer), $8 \mathrm{~mm}$ dithiothreitol, $100 \mathrm{~nm}$ NeoA primer, 30 units of RNasin (Promega) and 200 units of superscript reverse transcriptase (GIBCO-BRL). DNA/RNA hybrids were treated (30 min at $\left.37^{\circ} \mathrm{C}\right)$ with RNase $\mathrm{A}(10 \mu \mathrm{g}$, Boehringer/Mannheim) and RNase $\mathrm{H}(2.5 \mathrm{U}, \mathrm{GIBCO}-\mathrm{BRL})$, and excess primer was removed by centrifugation through a Qiagen spin column according to the manufacturer's instructions. Poly $(\mathrm{A})^{+}$tracts were added to the first-strand products by using terminal transferase in a $20-\mu \mathrm{l}$ reaction $\left(15 \mathrm{~min}, 37^{\circ} \mathrm{C}\right)$ containing $1 \times$ terminal transferase buffer (GIBCO-BRL), $160 \mu \mathrm{M}$ dATP and 15 units of terminal transferase (GIBCO-BRL). The tailed first strand product $(15 \mu \mathrm{l})$ was subjected to 10 cycles of PCR $\left(1 \mathrm{~min}\right.$ at $90^{\circ} \mathrm{C} ; 2 \mathrm{~min}$ at $55^{\circ} \mathrm{C}$; 3 min at $72^{\circ}$ ) in $100 \mu 1$ of $1 \times$ PCR buffer (Perkin-Elmer) and 0.5 units of Taq polymerase (Perkin-Elmer). Aliquots $(10 \mu)$ of the first PCR product were amplified for 45 cycles using $1 \mathrm{mM} \mathrm{Neo}$ $C$ primer, and $1 \mathrm{~mm}$ adaptor primer as before.

\section{DNA sequencing}

Plasmid DNA $(5 \mu \mathrm{g})$ was used in each sequencing reaction as described (Hsiao 1991), with the following modifications: (1) a $1: 8$ dilution of the G-mix was used; (2) termination reaction used $1.0 \mu \mathrm{l}$ of termination and $1.5 \mu$ l of extension mix; (3) labeling was for $4 \mathrm{~min}$ at room temperature; and (4) termination was for $5 \mathrm{~min}$ at $37^{\circ} \mathrm{C}$. All reactions, after labeling, were incubated in 96-well plates (conical bottom), and were initiated and terminated by centrifugation. Initial sequences were obtained by using $\mathrm{T} 3$ and $\mathrm{T} 7$ primers and later extended by using custom 17- to 18-nucleotide primers (Oligos, Etc.).

Two microliters of each sequencing reaction was loaded onto a Betagen AutoTrans apparatus. The gels $6 \%$ (19:1 acryl./bis) Sequagel [EC-833 from National Diagnostics], were prerun at 825 constant volts for 30-60 min. Free nucleotides were electrophoresed into a small strip of nylon membrane, and the membrane was changed. Gels were run at 825 constant volts and transferred onto $60 \mathrm{~cm}$ of membrane at a 1.5 web speed and a 450 -min web time.

\section{Whole-mount in situ hybridization}

Detailed methods for whole-mount in situ hybridization were based on procedures provided by Jill McMahon (Roche Institute, Nutley) and have been described elsewhere (Sasaki and Hogan 1993). Fixed and detergent-permeabilized embryos were hybridized to single-stranded RNA probes synthesized in vitro using UTP labeled with the plant steroid digoxigenin (DIG-11-UTP). The DIG-labeled RNA was localized using a conjugate of antidigoxigenin Fab antibody and calf intestinal alkaline phosphatase. The enzyme activity of the reporter was detected by a color reaction with 5-bromo-4-chloro-3-indolyl phosphate $(\mathrm{BCIP})$ and nitroblue tetrazolium (NBT), resulting in the formation of a water-insoluble purple precipitate. The yield of labeled probe was assessed before use by gel electrophoresis and by testing dilutions spotted onto a nylon filter for color reaction. Embryos were timed from the day of plugging (noon $=\mathrm{E} 0.5$ ).

\section{Interspecific backcross mapping}

Interspecific backcross progeny were generated by mating $\mid \mathrm{C} 57 \mathrm{BL} / 6] \times M$. spretus $\mid \mathrm{F}_{1}$ females and $\mathrm{C} 57 \mathrm{BL} / 6 \mathrm{~J}$ males as de- 
scribed (Copeland and Jenkins 1991). A total of $205 \mathrm{~N}_{2}$ mice were used to map the fug1 locus (see text for details). DNA isolation, restriction enzyme digestion, agarose gel electrophoresis, Southern blot transfer, and hybridization were performed essentially as described (Jenkins et al. 1982). All blots were prepared with Zetabind nylon membrane (AMF-Cuno). The probe (310-bp 1B6-6 cDNA) was labeled with $\left[\alpha^{32}\right] \mathrm{dCTP}$ using a nick translation labeling kit (Boehringer Manheim); washing was done to a final stringency of $2.0 \times \mathrm{SSCP}, 0.1 \%$ SDS at $65^{\circ} \mathrm{C}$. A major fragment of $7.5 \mathrm{~kb}$ was detected in HincII-digested C57BL/6J DNA, and a major fragment of $6.8 \mathrm{~kb}$ was detected in $H$ incII-digested $M$. spretus DNA. The presence or absence of the 6.8-kb M. spretus-specific HincII fragment was followed in backcross mice.

A description of the probes and RFLPs for the loci linked to Fug1, including $T g n$, Sis, and Gcdl, has been reported previously (Brannan et al. 1992). Recombination distances were calculated as described (Green 1981) using the computer program SPRETUS MADNESS. Gene order was determined by minimizing the number of recombinational events required to explain the allele distribution patterns.

\section{Acknowledgments}

We thank Brigid Hogan and Hiroshi Sasaki for assistance with in situ hybridization and for many helpful discussions; D.J. Gilbert; Brigid Hogan and Tsusumu Tonegawa for providing cDNA libraries; Michael Roshon for performing the zoo blot, and Clark Tibbetts and Donna Russel for help in using the $\mathrm{Au}$ totrans. This work was supported by grants from the National Institutes of Health (R01GM84688 to H.E.R.), the Deutsche Forschungegemeinschaft (Ho 684/2-1 to H.v.M.) and the National Cancer Institute, Department of Health and Human Services (under contract NO1-CO-74101 to N.A.J. and N.G.C.).

The publication costs of this article were defrayed in part by payment of page charges. This article must therefore be hereby marked "advertisement" in accordance with 18 USC section 1734 solely to indicate this fact.

\section{References}

Atkinson, N.S., R.W. Dunst, and A.K. Hopper. 1985. Characterization of an essential Saccharomyces cerevisiae gene related to RNA processing: cloning of RNAl and generation of a new allele with a novel phenotype. Mol. Cell Biol. 5: 907915.

Brannan, C.I., D.J. Gilbert, J.D. Ceci, Y. Matsuda, V.M. Chapman, J.A. Mercer, H. Eisen, L.A. Johnston, N.G. Copeland, and N.A. Jenkins. 1992. An interspecific linkage map of mouse chromosome 15 positioned with respect to the centromere. Genomics 13: 1075-1081.

Cedar, H. and A. Razin. 1990. DNA methylation and development. Biochem. Biophys. Acta. 1049: 1-8.

Chang, W., C. Hubbard, C. Friedel, and H.E. Ruley. 1993. Enrichment of insertional mutants following retrovirus gene trap selection. Virology 193: 737-747.

Copeland, N.G. and N.A. Jenkins. 1991. Development and applications of a molecular genetic linkage map of the mouse genome. Trends Genet. 7: 113-118.

Feinberg, A.P. and B. Volgelstein. 1984. A technique for radiolabeling DNA restriction fragments to high specific activity. Anal. Biochem. 137: 266-267.

Fleischmann, M., M.W. Clark, W. Forrester, M. Wickens, T. Nishimoto, and M. Aebi. 1991. Analysis of yeast prp20 mutations and functional complementation by the human ho- mologue $\mathrm{RCCl}$, a protein involved in the control of chromosome condensation. Mol. Gen. Genet. 227: 417-423.

Forrester, W., F. Stutz, M. Rosbash, and M. Wickens. 1992. Defects in mRNA 3 -end formation, transcription initiation, and mRNA transport associated with the yeast mutation prp20: Possible coupling of mRNA processing and chromatin structure. Genes \& Dev. 6: 1914-1926.

Friedrich, G. and P. Soriano. 1991. Promoter traps in embryonic stem cells: A genetic screen to identify and mutate developmental genes in mice. Genes \& Dev. 5: 1513-1523.

Frohman, M.A., M.K. Dush, and G.R. Martin. 1988. Rapid production of full-length cDNAs from rare transcripts: Amplification using a single gene-specific oligonucleotide primer. Proc. Natl. Acad. Sci. 85: 8998-9002.

Gossler, A., A.L. Joyner, J. Rossant, and W.C. Skarnes. 1989. Mouse embryonic stem cells and reporter constructs to detect developmentally regulated genes. Science 244: 463-465.

Green, E.L. 1981. Linkage, recombination, and mapping. In Genetics and probability in animal breeding experiments, pp. 77-113. Oxford University Press, New York.

Green, M.C. 1989. Catalog of mutant genes and polymorphic loci. In Genetic variants and strains of the laboratory mouse (ed. M.F. Lyon and A.G. Searle), pp. 12-403. Oxford University Press, Oxford, U.K.

Gridley, T., D.A. Gray, T. Orr-Weaver, P. Soriano, D.E. Barton, U. Francke, and R. Jaenisch. 1990. Molecular analysis of the Mov 34 mutation: Transcript disrupted by proviral integration in mice is conserved in Drosophila. Development 109: $236-240$.

Herrmann, B.G., S. Labeit, A. Poustka, T.R. King, and H. Lehrach. 1990. Cloning of the $T$ gene required in mesoderm formation in the mouse. Nature 343: 617-622.

Hopper, A.K., F. Banks, and V. Evangelidis. 1978. A yeast mutant which accumulates precursor tRNAs. Cell 14: 21 1-219.

Hopper, A.K., H.M. Traglia, and R.W. Dunst. 1990. The yeast RNAl gene product necessary for RNA processing is located in the cytosol and apparently excluded from the nucleus. $I$ Cell Biol. 111: 309-321.

Hsiao, K. 1991. A fast and simple procedure for sequencing double stranded DNA with Sequenase. Nucleic Acids Res. 19: 2787 .

Innis, M.A., D.H. Gelfand, J.J. Sninsky, and T.J. White. 1990. PCR protocols: A guide to methods and applications. Academic Press, San Diego, CA.

Jenkins, N.A., N.G. Copeland, B.A. Taylor, and B.K. Lee. 1982. Organization, distribution, and stability of endogenous ecotropic murine leukemia virus DNA sequences in chromosomes of Mus musculus. /. Virol. 43: 26-36.

Johnson, M.H. 1981. The molecular and cellular basis of preimplantation mouse development. Biol. Rev. 56: 463-498.

Kafri, T., M. Ariel, M. Brandeis, R. Shemer, L. Urven, J. McCarrey, H. Cedar, and A. Razin. 1992. Developmental pattern of gene-specific DNA methylation in the mouse embryo and germ line. Genes \& Dev. 6: 705-714.

Kozak, M. 1991. Structural features in eukaryotic mRNAs that modulate the initiation of translation. I. Biol. Chem. 266: $19867-19870$.

Laird, P.W., A. Zijderveld, K. Linders, M.A. Rudnicki, R. Jaenisch, and A. Berns. 1991. Simplified mammalian DNA isolation procedure. Nucleic Acids Res. 19: 4293.

Lawson, K.A. and R.A. Pedersen. 1992. Clonal analysis of cell fate during gastrulation and early neurulation in the mouse. In Postimplantation development in the mouse. (ed. D.J. Chadwick and J. Marsh), pp. 3-21. John Wiley and Sons, Chichester, United Kingdom.

Lee, J.J., G. Radice, C.P. Perkins, and F. Costantini. 1992. Iden- 
tification and characterization of a novel, evolutionarily conserved gene disrupted by the murine H beta 58 embryonic lethal transgene insertion. Development 115: 277-288.

Lowy, D.R. and B.M. Willumsen. 1993. Function and regulation of RAS. Annu. Rev. Biochem. 62: 851-891.

Melchior, F., K. Weber, and V. Gerke. 1993. A functional homologue of the RNA1 gene product in Schizosaccharomyces pombe: Purification, biochemical characterization, and identification of a leucine-rich repeat motif. Mol. Biol. Cell 4: $569-581$.

Michaud, E.J., S.J. Bultman, L.J. Stubbs, and R.P. Woychik. 1993. The embryonic lethality of homozygous lethal yellow mice $\left(\mathrm{A}^{y} / \mathrm{A}^{\mathrm{y}}\right)$ is associated with the disruption of a novel RNAbinding protein. Genes \& Dev. 7: 1203-1213.

Pearson, N.J., P.C. Thorburn, and J.E. Haber. 1982. A suppressor of temperature-sensitive rna mutations that affect mRNA metabolism in Saccharomyces cerevisiae. Mol. Cell. Biol. 2: $571-577$.

Pruitt, S.C. 1993. Expression of Pax-3- and neuroectoderm-inducing activities during differentitaion of P19 embryonal carcinoma cells. Development 116: $573-583$.

Reddy, S., J.V. DeGregori, H. von Melchner, and H.E. Ruley. 1991. Retrovirus promoter trap vector to induce lacZ gene fusions in mammalian cells. J. Virol. 65: 1507-1515.

Reddy, S., H. Rayburn, H. von Melchner, and H.E. Ruley. 1992. Fluorescence-activated sorting of totipotent embryonic stem cells expressing developmentally regulated lac Z fusion genes. Proc. Natl. Acad. Sci. 89: 6721-6725.

Sambrook, J., E.F. Fritsch, and T. Maniatis. 1989. Molecular cloning. A laboratory manual, 2nd ed. Cold Spring Harbor Laboratory Press, Cold Spring Harbor, New York.

Sasaki, H. and B.L.M. Hogan. 1993. Differential expression of multiple fork head related genes during gastrulation and axial pattern formation in the mouse embryo. Development 118: 47-59.

Sawicki, J.A., T. Magnuson, and C.J. Epstein. 1981. Evidence for expression of the paternal genome in the two-cell mouse embryo. Nature 294: 450-451.

Schneider, R. and M. Schweiger. 1992. The yeast RNAl protein, necessary for RNA processing, is homologous to the human ribonuclease/angiogenin inhibitor (RAI). Mol. Gen. Genet. 233: 315-318.

Skarnes, W.C., B.A. Auerbach, and A. Joyner. 1992. A gene trap approach in mouse embryonic stem cells: The lac $Z$ reporter is activated by splicing reflects endogenous gene expression, and is mutagenic in mice. Genes \& Dev. 6: 903-918.

Theiler, K. 1989. The house mouse: Atlas of embryonic development. Springer-Verlag, New York.

Titus, D.E. 1991. Promega protocols and applications guide. Promega Corporation, Madison, WI.

Traglia, H.M., N.S. Atkinson, and A.K. Hopper. 1989. Structural and functional analyses of Saccharomyces cerevisiae wildtype and mutant RNAI genes. Mol. Cell. Biol. 9: 2989-2999.

Tung, K., L. Norbeck, S. Nolan, N. Atkinson, and A. Hopper. 1992. SRN1, a yeast gene involved in RNA processing, is identical to $H E X 2 / R E G 1$, a negative regulator in glucose repression. Mol. Cell. Biol. 12: 2673-2680.

Vankin, G.L. and E.W. Caspari. 1979. Developmental studies of the lethal gene Bld in the mouse. I. Embryol. Exp. Morphol. 49: 1-12.

von Melchner, H. and H.E. Ruley. 1989. Identification of cellular promoters by using a retrovirus promoter trap. I. Virol. 63: 3227-3233.

von Melchner, H., J.V. DeGregori, H. Rayburn, S. Reddy, C. Friedel, and H.E. Ruley. 1992. Selective disruption of genes expressed in totipotent embryonal stem cells. Genes \& Dev.
6: 919-927.

Watson, M.L. 1968. Blind-a dominant mutation in mice. $/$. Hered. 59: 60-64.

Zhou, X., H. Sasaki, L. Lowe, B. Hogan, and M. Kuehn. 1993. Nodal is a novel TGF- $\beta$-like gene expressed in the mouse node during gastrulation. Nature 361: 543-547. 


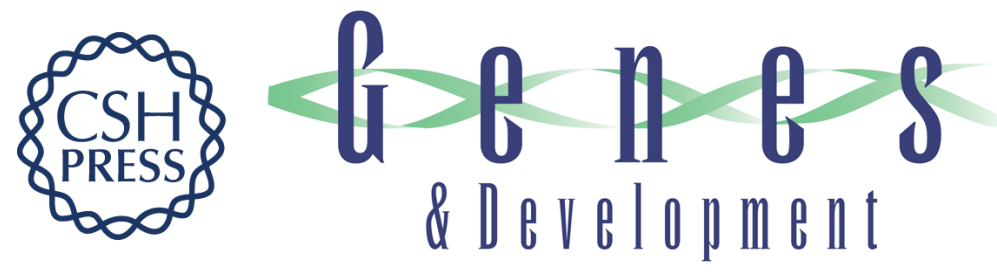

\section{A murine homolog of the yeast RNA1 gene is required for postimplantation development.}

J DeGregori, A Russ, $\mathrm{H}$ von Melchner, et al.

Genes Dev. 1994, 8:

Access the most recent version at doi:10.1101/gad.8.3.265

References This article cites 40 articles, 21 of which can be accessed free at:

http://genesdev.cshlp.org/content/8/3/265.full.html\#ref-list-1

License

Email Alerting Receive free email alerts when new articles cite this article - sign up in the box at the top Service right corner of the article or click here.

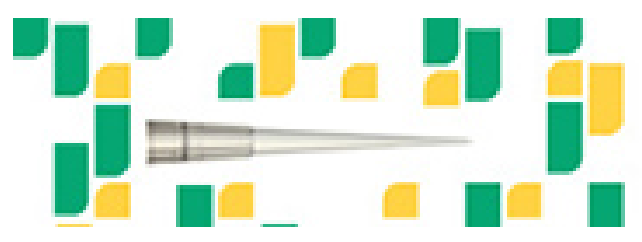

Focused on your science. 